\title{
5G, Religion, and Misconceptions in Communication during Covid-19 in Nigeria
}

\author{
Ben-Collins Emeka Ndinojuo ${ }^{1}$ \\ ${ }^{1}$ Department of Linguistics and Communication Studies, University of Port Harcourt, \\ PMB 5323 Choba, Port Harcourt, Rivers State, Nigeria \\ *Corresponding author, e-mail: becoolholly@gmail.com
}

\begin{abstract}
$5 G$ was test-launched in Nigeria in 2019 to improve its communication technology, conspiracy theorists, however, linked $5 G$ to the outbreak of the Covid-19. As with conspiracies, the 'who' that lends credence to it affects how far it travels. Pastor Chris Oyakhilome, founder of Believers LoveWorld, added his voice to the $5 G$ debate, claiming that Covid-19 lockdown was decoy to sequester the population for government to covertly deploy $5 G$. This study is important because it addresses the issue of fake news and its ability to cause civil disobedience in the society. Using secondary research method, content analysis was used to review arguments on $5 G$ controversy in the Nigerian context. Findings revealed that government appealed for calm and stated that no license for the installation of $5 G$ has been issued yet. Technology enthusiasts and media organizations put out fact-checking information in support of the technology. Various arguments indicate that no one really understands the full capabilities of $5 G$ and its long-term effect on living organisms and the environment. It is recommended that more tests be carried out in varying conditions to understand the tolerance limit of the technology, and for the government to be transparent in its public communication.
\end{abstract}

Keywords: 5G, Covid-19, Misconceptions in Communication, Public Health, Nigeria.

\section{Introduction}

$5 \mathrm{G}$ wireless communication was test run in Abuja, Nigeria in November 2019 by the largest telecommunications network in Nigeria, MTN Nigeria. It was the first 5G trial in West Africa; it followed a successful trial conducted by MTN South Africa in June 2018. The demonstration highlighted the deliverables of 5G wireless communication network which includes swift automation and rapid immersive entertainment (Awojulugbe, 2020) it, however, failed to address salient issues such as Nigeria's readiness for a nationwide rollout especially due to its well documented epileptic power supply as well as questions on the safety of the technology to human, other living organism and the environment where the technology would be deployed. This paper argues about the need for full disclosure as regards the new technology in order to understand its capabilities and effects on living organisms and the environment. To achieve this, it is important to understand what has been documented, what is covered and the ramifications of the adoption of the technology.

Tracing back to the origins of wireless technology, scholars inform that the first generations of hand-held mobile devices were available in a few countries for private and commercial use towards late ' 80 's. Successively, the second (2G), third (3G), and fourth (4G, LTE) generations were introduced with a greater rate of adoption and penetration with each release (Simkó \& Mattsson, 2019). The newest addition to the technological evolution is the $5 \mathrm{G}$ network, and like the previous releases, skeptics have raised doubts about its safety on health and environment. Furthermore, 5G is arguably the base technology for the Internet of Things (IoT). 
Table 1. Subdivision of the $5 \mathrm{G}$ frequency spectrum

\begin{tabular}{ccc}
\hline Frequency Range & Use & Comments \\
\hline$<1 \mathrm{GHz}$ & Net coverage, IoT & $\begin{array}{c}\text { Already in operation in earlier MP generations, } \\
\text { longer range coverage, and less costly } \\
\text { infrastructure }\end{array}$ \\
$1-6 \mathrm{GHz}$ & $\begin{array}{c}\text { Net coverage, IoT, } \\
\text { Ability to transfer data }\end{array}$ & $\begin{array}{c}\text { More spectrum available, shorter range and } \\
\text { reduced performance compared to higher } \\
\text { frequencies }\end{array}$ \\
$>6 \mathrm{GHz}$ & $\begin{array}{c}\text { Ability to transfer very } \\
\text { high data }\end{array}$ & $\begin{array}{c}\text { Short range, allows high speed data transfer } \\
\text { and short latency times }\end{array}$ \\
\hline
\end{tabular}

Note: Adapted from Simkó and Mattsson, (2019)

$5 \mathrm{G}$ networks will include higher millimeter-wave frequencies that have not been used in the past for internet technology (see Table 1). 5G distribution is expected to increase frequencies in the microwave band in the low- $(0.6 \mathrm{GHz}-3.7 \mathrm{GHz})$, mid$(3.7 \mathrm{GHz}-24 \mathrm{GHz})$, and high-band frequencies (24 GHz and higher) for instantaneous transmissions (Verma et al., 2019). They continue that these higher frequencies travel short distances and are obstructed by buildings, thus, the system requires a dense network of static outdoor antennas every 300 meters as well as indoor systems. The problem here becomes the higher exposure to radiation, and as seen with $2 \mathrm{G}, 3 \mathrm{G}, 4 \mathrm{G}$ infrastructure, the $5 \mathrm{G}$ system yet to be pre-market tested for long-term health effects despite the fact that people will be exposed continuously to this microwave radiation. To pre-test will mean many years of delay before deployment, hence, the public becomes guinea pigs for the trial of its electromagnetic spectrum transmitted between the antennae or mast and a handheld mobile device. This uncertainty is what gives rise to conspiracy theories, where at one end; the companies are accused of placing value on profit over the health of living organisms and the environment; while at the other end, the companies tout the supersonic availability of information on the network as an overriding factor over its marginal health concerns.

Reports have been published to allay public concerns over the impending rollout of 5G network services and its link to the novel Covid-19 virus that has impacted the globe leading to shut down of many countries and economies (Broad, 2019; Finley, 2019; Waterson \& Hern, 2020). Waterson and Hern (2020) describe such claims as baseless and 'dangerous nonsense.' They allude that part of the problem of challenging $5 \mathrm{G}$ conspiracy theories is a shortcoming by network providers to advance empirical and scientific evidence about the capabilities of $5 \mathrm{G}$, coupled with an alarmed public trying to make sense of a chaotic world. The government and phone networks are struggling to convince the public, making them turn on telecommunication engineers and attacks on masts expected to carry 5G facilities and infrastructure (Ogundipe, 2020). Some of these conspirators are said to organize on Whatsapp and Facebook groups where they share among themselves and their network, information that has no factual bases. The violence increased with the imposition of lockdowns, spreading more fears as people do not know what to expect next while governments struggle to grasp the magnitude of the impact of the novel virus.

The fact that Wuhan acknowledged 5G coverage in August 2019, nearly eighteen (18) months after it was launched in London by $\mathrm{O} 2$ network did not stop the rumor that the first city in the world to receive the $5 \mathrm{G}$ network was Wuhan, China. Interestingly, Iran, one of the hardest hit nations by the novel coronavirus virus is yet to rollout any $5 \mathrm{G}$ 
coverage. With the increased attention received by the debate on social media, some unreliable media organizations have seen the controversy as an avenue to generate clickbaits. The Daily Star according to the press regulation campaign group 'Hacked Off' published an article on March 24, a day after the UK Prime Minister ordered lockdown in the UK--with the banner head line "Coronavirus: Fears $5 G$ Wi-Fi networks could be acting as 'accelerator' for disease." The report was dubbed an exclusive and was based solely on citations from non-scientists. The social media giant, Facebook also announced it would, moving forward, vigorously delete fake claims that associate Covid19 to $5 \mathrm{G}$ and physical damage or harm (Waterson \& Hern, 2020).

Nothing fans the flames of conspiracies theories than during uncertainties occasioned like those we are witnessing. This occurrence is exceptionally dire due to the paucity of reliable scientific unanimity on the spread, containment, and long-term social and economic effects of Covid-19 on the society. With the world at odds on how best to tackle the pandemic, conspiracy theorists advanced different origins, management, and reasons for its spread. One of the reasons attributed to the spread of the virus is the need for governments to covertly install $5 \mathrm{G}$ network infrastructure for the mass application of the $5 \mathrm{G}$ technology to society. At the heart of the matter would be the profit margins accruable to the owners of the network and the governments that would grant licenses to investor companies. Douglas et al. (2019) consider 'conspiracy' as a secret plot by two or more powerful individuals or groups. The idea is to usurp political or economic power, violate rights, infringe upon established agreements, withhold vital secrets, or alter bedrock institutions (Grzesiak-Feldman, 2013; Radnitz \& Underwood, 2017; Zarefsky, 2014).

Juxtaposing this definition with the conspiracies of 5G technology in the Covid-19 Pandemic lends some credence to the conspiracy theorists. The global lockdowns put in place to check the spread of the virus towards the end of February 2020, has led to governments usurping political and economic powers; businesses have been shuttered with threats of arrest for those who attempt to or break the imposed shutdowns (Bamidele, 2020; Britschgi, 2020; Pereira, 2020) political powers have also been usurped as some (Chappell, 2020; Daily Sabah, 2020; Lubold \& Hinshaw, 2011) democratic processes have been halted in order to check the spread of the virus (Corasaniti \& Stephanie Saul, 2020; Dunai, 2020; Gebrekidan, 2020; Mohamed, 2020; Wallace \& Palder, 2020). People have been denied the right to movement, congregation, religious worship, etc. which are all guaranteed in the constitutions of most countries of the free world. Allegations of withholding secrets have also been leveled against China and WHO most especially by The United States and other countries (Chappell, 2020; Daily Sabah, 2020; Lubold \& Hinshaw, 2011). The restrictions have also led to the shutdowns of vital educational and research institutions. However, I argue that there is not much evidence to associate $5 \mathrm{G}$ and Covid-19 in the realm of conspiracy theory.

According to Van Prooijen and Douglas (2017) the aim of conspiracy theories is to assign causes of significant social and political events to secret plots by powerful actors. They agree that some conspiracy theories are true; however, most are usually false alarms lacking evidential support. These matters are discussed in detail in Douglas et al. (2019). Examples include the claim that the president of Nigeria Mohammed Buhari is dead and has been replaced by a clone, Jubril from Sudan (Stanley-Becker, 2018) the plot linking the US government to the assassination of President Kennedy and 9/11 New York terror attacks (Sunstein \& Vermeule, 2009), that democratic bankers caused the global economic meltdown in order to get Barack Obama elected in 2008 (Van Prooijen \& 
Douglas, 2017), European Jews being blamed for failures during the Crusades and for causing disease epidemics (Brotherton, 2015), and many other such conspiracies. These outlandish claims have no evidence in support. They have been largely amplified by the rise of the internet, with access largely ubiquitous globally (Oliver \& Wood, 2014; Sunstein \& Vermeule, 2009), conspiracy theories seem to be thriving as anyone can make up any conspiracy, and with the reach of the internet aided by social media and hashtags, conspiracies target specific vulnerable groups by reinforcing impressions about the nonexistence of the pandemic, thereby opening the mind to conspiracy theories unknowingly as argued by Douglas and Sutton (2008). This has been addressed as the desire of the population to make sense of the events beyond their comprehension (Bale, 2007; Van den Bos, 2009) Being susceptible to one conspiracy makes an individual vulnerable to other conspiracies because once the mind absorbs the cause and effect to address one issue, the likelihood of inferring the same in other scenarios increases. This was captured succinctly by Wood, Douglas, and Sutton (2012).

\section{Methods}

The study made use of secondary research methods, this has been validated scholarly (Andrews et al., 2012; Johnston, 2014; Russell, 2001). Secondary data is data collected by others for another primary purpose. The use of this preexisting data in new research is an alternative for researchers hindered by time or money (Johnston, 2014), and in the age of Covid-19, this becomes more relevant with the restrictions on (Sukmono \& Junaedi, 2019; Yustitia, 2010) movement to curtail the spread of the virus, online sources of research is thus indispensable, and has also been applied to citizen journalism.

The research population included scholarly works and news articles purposively selected. They illuminate discourse on 5G and controversies linking it to Covid-19 lockdown in Nigeria especially around the views expressed by Pastor Chris Oyakhilome during the pandemic. Newspapers (online), magazines, academic journals, textbooks, radio, and television are good sources of secondary data in conducting research. The study utilized qualitative research using keywords search to find relevant information for the study. Keywords such as 5G, 5G, and Covid-19, Covid-19 conspiracy, Pastor Chris was used to generate data that were analyzed and presented using discourse analysis.

\section{Results}

Health concerns over the short and long term effects of $5 \mathrm{G}$ to humans and the environment have been raised over time (Waldmann-Selsam et al., 2016). In an appeal to the European Union, more than 180 doctors and scientists from 36 countries warned about the dangers of $5 \mathrm{G}$ rollout, which will lead to an increase in involuntary exposure to electromagnetic radiation (Carlberg \& Hardell, 2017; Hardell, 2017; Hardell \& Nyberg, 2020; Panagopoulos, 2019). Feldman et al.(2009) raised concerns over the ability of the human skin to act as antennas and therefore respond to millimeter waves when they established that sweat ducts on human skin are helically-shaped tubes, overflowing by means of a conductive aqueous solution.

There are also concerns for effects of $5 \mathrm{G}$ applications on the eyes as it would receive some degree of radiation especially for near field exposures which could lead to cataract of the eye, one of the causes of blindness, with literature that has recognized the factors associated with its development to include; diabetes, smoking, age, and UVB exposure. However, in a 2014 study, the World Health Organization (WHO) stated that "no adverse health effects have been established as being caused by mobile phone use." However, the 
WHO in conjunction with the International Agency for Research on Cancer (IARC) classified all radio-frequency radiation (which includes mobile signals) as 'possibly carcinogenic,' because there is no conclusive evidence that exposure may cause cancer in humans, also, usage of talcum powder and eating pickled vegetables are included in this classification. In addition, the radio waveband deployed in mobile phones is non-ionizing, meaning it lacks adequate energy to affect DNA that can lead to cellular damage (Foster, 2019; Reality Check, 2019).

In a clinical trial of the effect of $5 \mathrm{G}$ on rats in 2018, a report by the United States Department of Health established that exposure of male rats to elevated dosage of radiofrequency radiation caused a type of cancerous heart tumor. In the research, whole bodies of rats' were exposed to radiation from mobile telephones starting from before they were born, nine (9) hours a day everyday for two (2) years. There was no direct link to cancer found in the female rats or the mice studied. Findings showed that rats exposed to the radiation surprisingly survived longer than the control group (Reality Check, 2019). Similar findings were detailed in a study by Falcioni etal.(2018) released after those carried out by the US Department of Health, it corroborated the health risks associated with radio base station emissions. The research precisely, reports an increase in the incidence of brain and heart tumors in Sprague-Dawley rats exposed to EMF generated by a radio base station. It observed a statistically significant increase in the incidence of heart Schwannomas in treated male rats already at exposure levels much lower than those considered in the US study, consistent with those experienced by people on a daily basis (Chiaraviglio et al., 2019). Foster (2019) reported that $12 \%$ of respondents in in study in Europe were 'endearingly concerned' about exposure to wireless base stations, broadcast facilities, and mobile phone and other new technologies.

The clear observation in all the studies is the lack of conclusivity and definitiveness about the expected health impacts of the 5G network. As is with most new technologies, there are always reservations about their impacts on one hand (Adelakun, 2020), and on the other hand, no country, especially the developed nations, want to be left behind in the tech war as there may be far-reaching consequences in military, health, and wellbeing, industrial applications, technology, banking, and financial services, urbanization, and other facets of possible 5G application. The cost of being left behind is enormous and may mean depending on a competing nation for essential services. To a developing nation like Nigeria, this may not bear any significance as it is mainly a consumer nation depending mainly on imports even for a commodity like petrol motor spirit irrespective of the abundance of crude oil in the country, but for a nation like the USA, losing the 5G war to China or any other country would create an unfavorable balance of trade and loss of economic jobs.

$5 \mathrm{G}$ and Religious Controversy in Nigeria

Religion is highly sacred in Nigeria, the two most popular are Christianity and Islam. It is commonplace to see politicians in churches and mosques to receive the blessing and support of preachers especially during periods leading up to elections. Maybe it is because the politicians need God's blessing in their aspiration or to show the religious electorate that they are traditional people and have reverence for God or Allah as the case may be. What is, however, undeniable is that the politicians need the votes of the religious community, which in turn depends on the leader of the congregation; An Imam if it is Islamic religion and a Priest/Bishop/Pastor if it is the Christian community. Towards any election, the congregation faithful waits on their spiritual leader for guidance, and they go out en masse to support such a candidate, and after the election, the 
winner reciprocates by visiting the religious organizations that supported their emergence (Ago, 2017). Because the companies responsible for 5G technology are not politicians but business entities, the view of the religious was not considered until Pastor Chris Oyakhilome (also called Pastor Chris), founder and president of Believers LoveWorld Inc. popularly called Christ Embassy, based in Lagos, Nigeria joined the 5G debate.

He boasts a worldwide membership of 13 million members (Haylon, 2018), with churches in 145 branches on five continents (The Punch, 2019). The church started with a prayer group led by Pastor Chris, at Ambrose Alli University, Ekpoma, Edo State, Nigeria, while he was studying architecture in 1987 and grew to its current height. He organized the biggest one-night event in Nigeria with an estimated 3.5 million people attending tagged 'Good Friday Miracle Night,' and over two million fans on Facebook in 2005. Pastor Chris 'is also the author of the daily devotional Rhapsody of Realities.' The rhapsody of realities daily devotional book is made available in over 1000 languages, can be downloaded online, and is the second most translated book in the world after the bible (Falaye, 2015).

The pastor has been involved in quite a number of controversial statements and is not shy of sharing his views. He has been criticized by the Treatment Action Campaign for supporting faith healing in the treatment of HIV/AIDS and cure of tumors if rebuked through his Rhapsody of Realities (Lubold \& Hinshaw, 2011). He claimed that the institution of marriage between a husband and a wife is akin to a master and a servant, where the wife exists to serve and please her husband (Byte, 2016). Others have accused him of preaching prosperity gospel and using his followers for money, explicitly promising those who donate to his ministry will be rewarded with health, wealth. and good fortune (Kuoppamäki, 2017). Breaking off from traditionally held conservative views in Nigeria, Pastor Chris made a statement in support of abortion especially in the case of rape, and he affirmed the woman should have the choice to terminate or keep the baby (The Pulse, 2014). With the global lockdown in place to forestall the spread of the novel coronavirus, Pastor Chris added his voice to the $5 \mathrm{G}$ debate. In a message that was broadcast on YouTube, Pastor Chris claimed that the lockdown of Lagos and Abuja was to enable the Nigeria Government put in place $5 \mathrm{G}$ infrastructure. According to his assertion, "The federal government was pushed to lockdown Abuja and Lagos specifically. Why? Because of $5 G$ in Abuja and Lagos. They already tested $5 G$ in Abuja and they are engaging it already in Lagos. That's the reason the federal government had to lockdown Abuja and Lagos. So the $5 G$ could be installed. There are other cities planned for" (Augoye, 2020).

He continued that what led to the deaths in Wuhan, was not coronavirus, but $5 \mathrm{G}$, and claimed that there is a global deception to deceive the global population to the true situation the world was dealing with. He adds that if the virus is claimed to be airborne, then isolation or staying at home cannot save anyone from the virus. He stated that the reason for the social distancing campaign was to make sure people could not gather to protest and or communicate with one another when the effects of 5G start manifesting, thus, the best way of striking fear into the population is to stoke the existence of a phantom and deadly virus. Categorically, he states that this should not be seen as a conspiracy theory but rather a proven reality, a fact, and an antichrist initiative. He also claims that the images being shared on the internet about the impact of the virus may be doctored images. "They carry photos from China, or from Italy, or Spain and show to the Americans, show to the British. You see things like oh this is really happening, but it's not. They do not tell what's killing the people. Two things are killing the people. The first 
one is where those 5G signals are being tested and have been turned on. A lot of people died. This is real. Number two, where are the people that normally got sick with the flu? Where are they? Nobody is talking about the flu right now" (Augoye, 2020).

Analyzing his statement objectively, it falls within the sphere of conspiracy theory not necessary because he is wrong, but because he fails to provide any empirical foundation to his claims. The scientists who have opposed the rollout of $5 \mathrm{G}$ technology have done so based on its health implications on humans, not because of a new world order, about to take over governments in the world. This would be seen as one those moments the preacher would lend his voice to controversial statements in the society as he has done in the past. It was not surprising that after a few days, he released another statement that sort of backtracked on his earlier claims about 5G being the cause of the coronavirus. Pastor Chris stated that he was only opposed to $5 \mathrm{G}$ because of its perceived health risks and the seeming silence of authorized regulators to speak on its merits and demerits (Ojo, 2020). He seemed to now say that he was more concerned about the health implications of the technology and as a healing minister that cares and heals the sick, he would not like to see more people suffer. His initial statement was, however, followed by messages of support, criticism, and caution from different quarters.

\section{Discussion}

The statement from Pastor Chris led to a number of different reactions, from fellow preachers, politicians, media and the government of Nigeria. In his support Apostle Johnson Suleiman, President of Omega Fire Ministries Worldwide chided critics of Pastor Chris to avoid name calling and instead present their own alternative facts to the matter (Augoye, 2020). Pastor Adewale Giwa of Awaiting The Second Coming of Jesus Christ Ministry, said those castigating Pastor Chris for his views are trying to inflame the emotions of the public to score points. He described them as 'rabble-rousers.' He continued that evil people are using the $5 \mathrm{G}$ network to lay the foundation for the coming of the antichrist, continuing that Jesus Christ warned the people not to be alarmed when they start seeing the signs (Opejobi, 2020).

A former government minister and government critic Chief Femi Fani-Kayode also is known for having controversial views on national issues issued a statement in support of Pastor Chris, praising his courage in speaking up against the forces of evil determined to introduce 5G that would lead to the coming of the antichrist (Opejobi, 2020). "Say or think what you like about Covid-19, 5G, Bill Gates, Elon Musk, the Corona vaccine, the Illuminati, the New World Order, the Pope, the Deep State, Artificial Intelligence, the Bilderberg Group, the Bohemian Grove, the One World Religion or the One World Economy and believe whatever you will. It changes absolutely nothing and it cannot bury the truth or stop God's counsel and plan from unfolding. Yet to be candid, what is inexplicable and utterly indefensible is for a 'man of God' to dismiss the provisions and words of the Holy Bible in the Book of Daniel and the Book of Revelations as a mere conspiracy theory. You either believe the Word of God or you do not. Scripture cannot be broken and the end-time prophecies shall be fulfilled. Covid-19 will come and go and so will $5 G$ and all sorts of other things that will be equally disturbing and shocking will come after them" (Daily Post, 2020). 
A former Senator, Dino Melaye also supported the idea of $5 \mathrm{G}$ being bad for the society, he posted a video to YouTube and shared on his Twitter account where he described 5G as a killer and must be resisted by the public (Asadu, 2020).

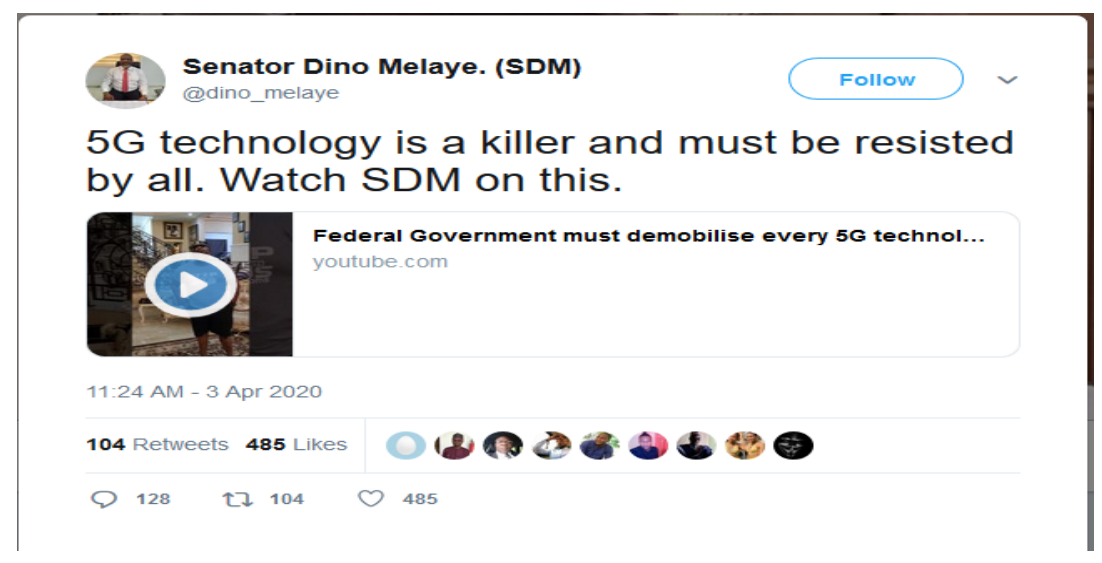

Figure 1. Senator Dino Melaye's Twitter opinion on 5G

On the other end of the spectrum, there were others opposed to the postulations of Pastor Chris on 5G. Three prominent preachers condemned the views according to the report by (Augoye, 2020). The three clerics, Poju Oyemade, Sam Adeyemi and Matthew Ashimolowo, discredited Oyakhilome's claims at different occasions. The senior pastor of Kingsway International Christian Centre in London, Ashimolowo, clarified that there was no correlation between the $5 \mathrm{G}$ technology and signs of the end-time, he enjoined adherents not to promote conspiracy theories. Adeyemi, of the Daystar Christian Centre, opined that churches, markets, schools and mosques were closed in 1918 in Nigeria during the influenza pandemic. He expressed this on an Instagram message he shared with Oyemade, the senior pastor of The Covenant Christian Center. Furthermore, he added that leaders should research issues before sharing with followers to avoid misleading them, he drew parallels with the current government reaction of shutting down the country to what happened in 1918, saying mosques, churches, and schools were also shut down to limit the spread of the influenza epidemic in 1918. Responding, Adeyemi spoke about the need to identify opportunities in every crisis, and thus it is the leader's prerogative to visualize the opportunities and not to project panic on followers.

The government also responded to the suggestions about the dangers of $5 \mathrm{G}$ and its links to the noel coronavirus. The government clarified that there was no correlation between $5 \mathrm{G}$ technology and coronavirus. It also informed that there was no deployment of $5 \mathrm{G}$ in Nigeria presently, there was, however, a test run in November 2019 for a phase of three (3) months, and that the test run was concluded and decommissioned. The trial run was to understudy any health, environmnetal or security issues that may be associated with the network. The government would continue to provide strong regulation of the nation's telecommunication industry by ensuring compliance to standards put in place by Operators of mobile networks and other licenses in the telecommunication industry to safeguard the heal and wellbeing of Nigerians (Osuagwu, 2020). The government's statement, however, failed to address some issues it raised, first, which areas were 5G technology deployed? Secondly, was there disclosure to the residents in those areas of the deployment of this technology and for the time period to enable them to make the decision of being exposed to radiation from 5G technology? These questions raise the need for 
transparency and accountability on the part of the government to build public trust in government statements.

Nigeria runs a very opaque government where secrecy is the order of the day. Akinrefon (2019) reported that the President, General Mohammadu Buhari in his campaign prior to the 2015 general elections promised to run an open government starting with a public declaration of his assets if he wins the presidential election. However, after his defeat of the incumbent, he backtracked on the public declaration of his assets and instead claimed that the assets needed to be verified by the concerned government agency before he can make them public. After much public pressure, his media adviser read out a list of assets purportedly belonging to the president, they never released the asset declaration form submitted to the Independent and Corrupt Practices Commission (ICPC).

The president also spent months in a UK hospital and failed to disclose to Nigerians the true nature of his ill-health (Adebayo \& Busari, 2018), and with the outbreak of the novel coronavirus, the president and his chief of staff were rumored to have contracted the virus, again, after days of playing hide-and-seek, the president revealed that he tested negative while his chief of staff was positive (Ramalan, 2020), he has been receiving treatment in a private facility, away from the regulations and protocols put in place to check the spread of the virus (Sahara Reporters, 2020). So far, the president has addressed Nigerians twice in over 21 days since the declaration of lockdown due to COVID-19 virus (The Source, 2020), this was after the usual hide-and-seek game associated with his government (Adebowale, 2020) both of the speeches look pre-recorded as no media organization was present to ask him questions to clarify the government's approach unlike other world leaders who provide regular updates in front of the media and answer questions to calm public fears (Smith, 2020).

Running an opaque government is what fuels conspiracy theories, and with a public where there is no trust between the government and the people, it becomes easy for anyone with a large following such as Pastor Chris to cause chaos by promoting scientifically unproven claims. It is left for the government to try and win back the confidence and the trust of the people by being transparent about its activities and carrying the people along in all aspects of governance.

The key issues observed with $5 \mathrm{G}$ rollout is lack of synergy in communication between the network providers and government on one hand and the general public and stakeholders in the communication business on the other hand. Megachurches in Nigeria have incorporated virtual media in their communication practices with their global audiences. One expects that they should be more excited about the launch of 5G networks as it will create a better experience for the congregation in the church and those joining from different locations. It is thus expected that when launching new technology in Nigeria, tech companies should endeavor to reach out to some of these mega-churches. The failure of networks to incorporate preachers in their $5 \mathrm{G}$ launch probably contributed to a great extent to the views of Pastor Chris. It is most likely that Chris was influenced by conspiracy theories and protests in London against 5G technology. It is advised that all stakeholders be considered in future launch, and because of the influence such mega pastors have, it may not be out of place to organize an outreach privately for them to serve as a platform to avail them of the many advantages of $5 \mathrm{G}$ to their ministries. Mega preachers are stakeholders in the $5 \mathrm{G}$ business because of the online ministries, they run and the $5 \mathrm{G}$ will help them spread their preaching ministries with live online services especially in the age of coronavirus where social distancing and lockdown situation has 
required people to worship from home. The $5 \mathrm{G}$ technology would not have come at a better time. In fact, the variable that should be of concern to the government and network providers is the affordability of $5 \mathrm{G}$ services since people are already complaining of the cost of data services in Nigeria, and the tech companies complain of the huge cost of maintaining infrastructure in Nigeria especially with the poor power supply situation (Adepetun, 2020), the fulcrum of the 5G discussion in Nigeria may have been focused in the wrong direction. It is time to get back on the right track.

\section{Conclusion}

The advent of the internet means the release of information by anyone with access at supersonic speeds, as such, anyone especially influencers with a large following can cause hysteria with unconfirmed and unverified information. This is more so important in the age of Covid-19 with different conflicting information about its origin and spread. The government owes the public transparency on issues capable of causing anxiety, religious leaders should refrain from putting out information from conspiracy theories that could lead to a breakdown of law and order. The media in their watchdog function should also ask the relevant questions and try to get the facts of any controversy from authorized government officials and experts in the field of discourse. Lack of timely information was one of the reasons for the global spread of the virus. The corporate sector also has an important role to play as the inability to shutter businesses early enough to limit the spread of the virus increased worldwide infection, the 5G controversies would have been minimal if the Covid-19 virus was controlled early enough.

\section{Conflict of Interest}

I certify that there is no conflict of interest with any financial, personal, or other relationships with other people or organization related to the material discussed in the manuscript.

\section{Acknowledgements}

The author would like to thank Twitter, and our colleagues for making this study a successful one by ensuring all the needed data are readily available.

\section{References}

Adebayo, B., \& Busari, S. (2018). Nigeria's President Buhari heads to UK for more medical treatments. CNN.Com. https://edition.cnn.com/2018/05/08/africa /nigeriabuhari-medical-leave/index.html

Adebowale, N. (2020). Coronavirus: Why Buhari is yet to address Nigerians - Lai Mohammed. Premium Times. https://www.premiumtimesng.com/news/headlines 1382671-coronavirus-why-buhari-is-yet-to-address-nigerians-lai-mohammed.html

Adelakun, A. (2020). Pastor Chris Oyakhilome has made history. Punch. https://punchng.com/pastor-chris-oyakhilome-has-made-history/

Adepetun, A. (2020). Power challenge threatens Nigeria's $5 G$ commercialization. The Guardian. https://guardian.ng/technology/power-challenge-threatens-nigerias-5gcommercialisation/

Ago, A. (2017). Gov. Wike kneels before Pastor David Ibiyeomie [Photos]. City Perople. http://www.citypeopleonline.com/gov-wike-kneels-pastor-david-ibiyeomiephotos/

Akinrefon, D. (2019). Declare your assets publicly, Afenifere tells Buhari. Vanguard. 
https://www.vanguardngr.com/2019/01/declare-your-assets-publicly-afeniferetells-buhari-2/

Andrews, L., Higgins, A., Andrews, M. W., \& Lalor, J. G. (2012). Classic grounded theory to analyse secondary data: Reality and reflections. The Grounded Theory Review, 11(1), 12-26.

Asadu, C. (2020). Fact check: Is there any link between $5 G$ and coronavirus? TheCable. https://www.thecable.ng/fact-check-is-there-any-link-between-5g-and-coronavirus

Augoye, J. (2020). $5 G$ controversy: Ashimolowo, Oyemade, Adeyemi counter Oyakhilome's claims. Premium Times. https://www.premiumtimesng.com/ news/top-news/386899-5g-controversy-ashimolowo-oyemade-adeyemi-counteroyakhilomes-claims.html

Awojulugbe, O. (2020). Explainer: What to know about 5G, COVID-19 and your security. TheCable. https://www.thecable.ng/explained-what-to-know-about-5gcovid-19-and-your-security

Bale, J. M. (2007). Political paranoia v. political realism: on distinguishing between bogus conspiracy theories and genuine conspiratorial politics. Patterns of Prejudice, 41, 45-60.

Bamidele, M. (2020). Reactions As Police Arrest 39 Persons At Lagos Strip Club During Lockdown. The Guardian. https://guardian.ng/life/reactions-as-police-arrest-39persons-at-lagos-strip-club-during-lockdown/

Britschgi, C. (2020). Undercover Cops Arrest 2 Women for Operating Home Beauty Businesses In Violation of Coronavirus Lockdown Order. Reason. https://reason.com/2020/04/27/undercover-cops-arrest-2-women-for-operatinghome-beauty-businesses-in-violation-of-coronavirus-lockdown-order/

Broad, W. J. (2019). The 5G Health Hazard That Isn't. The New York Times. https://www.nytimes.com/2019/07/16/science/5g-cellphones-wireless-cancer.html

Brotherton, R. (2015). Suspicious Minds: Why We Believe Conspiracy Theories. Bloomsbury Sigma.

Byte, N. S. (2016). astor Chris Oyakhilome tells married women - Your husband is your master and if you stop listening to him your beauty evaporates. Ghana Celebrities. https://www.ghanacelebrities.com/2016/09/09/pastor-chris-oyakhilome-tellsmarried-women-husband-master-stop-listening-beauty-evaporates/

Carlberg, M., \& Hardell, L. (2017). Evaluation of mobile phone and cordless phone use and glioma risk using the Bradford Hill viewpoints from 1965 on association or causation. BioMed Research International, 11, 1-17.

Chappell, B. (2020). Azar Accuses WHO Of Failure That "Cost Many Lives” In COVID19 Pandemic. Npr. https://www.npr.org/sections/coronavirus-liveupdates/2020/05/18/858151841/azar-accuses-who-of-failure-that-cost-many-livesin-covid-19-pandemic

Chiaraviglio, L., Fiore, M., \& Rossi, E. (2019). 5G Technology: Which risks from the health perspective? In The 5G Italy book 2019: A multiperspective view of 5G. In M. A. Marsan, N. Blefari, S. Buzzi, \& S. Palazzo (Eds.), marcofiore. marcofiore. http://www.marcofiore.online/

Corasaniti, N., \& Stephanie Saul, S. (2020). 16 states have postponed primaries during the pandemic. The New York Times. https://www.nytimes.com/article /2020campaign-primary-calendar-coronavirus.htm

Daily Post. (2020). Femi Fani-Kayode: 5G, pastors and the hordes of Mordor. Retrieved from. Daily Post. https://dailypost.ng/2020/04/07/femi-fani-kayode-5g-pastors- 
and-the-hordes-of-mordor/

Daily Sabah. (2020). Australia accuses China, Russia of COVID-19 misinformation. Daily Sabah. https://www.dailysabah.com/world/asia-pacific/australia-accuseschina-russia-of-covid-19-misinformation

Douglas, K. M., \& Sutton, R. M. (2008). The hidden impact of conspiracy theories: Perceived and actual influence of theories surrounding the death of Princess Diana. Journal of Social Psychology, 148(2), 210-222.

Douglas, K. M., Uscinski, J. E., Sutton, R. M., Cichocka, A., Nefes, T., Ang, C. S., \& Deravi, F. (2019). Understanding conspiracy theories. Advances in Political Psychology, 40(1), 3-35.

Dunai, M. (2020). Hungary's PM imposes lockdown, seeks more powers for govt to fight coronavirus. Reuters. https://www.reuters.com/article/us-health-coronavirushungary-restrictio/hungarys-pm-imposes-lockdown-seeks-more-powers-for-govtto-fight-coronavirus-idUSKBN21E0Q2

Falaye, T. A. (2015). The ministry of Christ Embassy, Lagos, Nigeria. European Researcher, 92(3), 230-236.

Falcioni, L. Bua, L., Tibaldi, E., Lauriola, M., De Angelis, L., Gnudi, F., Mandrioli, D., Manservigi, M., Manservisi, F., Manzoli, I., Menghetti, I., Montella, S., Panzacchi, R., Sgargi, D., Strollo, V., Vornoli, A., \& Belpoggi, F. (2018). Report of final results regarding brain and heart tumors in Sprague-Dawley rats exposed from prenatal life until natural death to mobile phone radiofrequency field representative of a $1.8 \mathrm{GHz}$ GSM base station environmental emission. Environmental Research, 165, 496503.

Feldman, Y., Puzenko, A., Ben Ishai, P., Caduff, A., Davidovich, I., Sakran, F., \& Agranat, A. J. (2009). The electromagnetic response of human skin in the millimetre and submillimetre wave range. Physics in Medicine and Biology, 54(11), 33413363.

Finley, K. (2019). Worried about 5G's health effects? Don't be. SCIENTIFIC AMERICAN. https://blogs.scientificamerican.com/observations/5g-is-cominghow-worried-should-we-be-about-the-health-risks/

Foster, K. (2019). 5G is coming: How worried should we be about the health risks? SCIENTIFIC AMERICAN. https://blogs.scientificamerican.com/observations/5gis-coming-how-worried-should-we-be-about-the-health-risks/

Gebrekidan, S. (2020). For Autocrats, and Others, Coronavirus Is a Chance to Grab Even More Power. The New York Times. https://www.nytimes.com/2020/03/30/world /europe/coronavirus-governments-power.html

Grzesiak-Feldman, M. (2013). The effect of high-anxiety situations on conspiracy thinking. Current Psychology, 32(1), 100-118.

Hardell, L. (2017). World Health Organization, radiofrequency radiation and health - a hard nut to crack (Review). International Journal of Oncology, 51, 405-413.

Hardell, L., \& Nyberg, R. (2020). Appeals that matter or not on a moratorium on the deployment of the fifth generation, 5G, for microwave radiation. Molecular and Clinical Oncology, 12(3), 247-257. https://doi.org/10.3892/mco.2020.1984

Haylon, E. (2018). Major Nigerian Evangelical leader emphasizes Christian solidarity during Israel visit. The Jerudslem Post. https://www.jpost.com/Israel-News/MajorNigerian-Evangelical-leader-emphasizes-Christian-solidarity-during-Israel-visit557871

Johnston, M. P. (2014). Secondary data analysis: A method of which the time has come. 
Qualitative and Quantitative Methods in Libraries, 3, 619-626.

Kuoppamäki, A. (2017). Preachers of prosperity: faith as business. DW. https://www.dw.com/en/preachers-of-prosperity-faith-as-business/a-38936708

Lubold, G., \& Hinshaw, D. (2011). TAC, church face-off over healing claims. Mail \& Guardian. https://mg.co.za/article/2011-02-07-tac-church-faceoff-over-healingclaims/

Mohamed, H. (2020). ow is the coronavirus pandemic affecting elections in Africa? Aljazeera. https://www.aljazeera.com/news/2020/04/coronavirus-pandemicaffecting-elections-africa-200409085324155.html

Ogundipe, S. (2020). Coronavirus: Britons go on rampage, destroy $5 G$ masts over 'baseless' conspiracy theory. Premium Times. https://www.premiumtimesng.com/news/more-news/385989-coronavirus-britonsgo-on-rampage-destroy-5g-masts-over-baseless-conspiracy-theory.html

Ojo, J. (2020). COVID-19, 5G Mix-up: Why Nigerians are worried On. Vanguard. https://www.vanguardngr.com/2020/04/covid-19-5g-mix-up-why-nigerians-areworried/

Oliver, J. E., \& Wood, T. J. (2014). Conspiracy theories and the paranoid style(s) of mass opinion. American Journal of Political Science, 58(4), 952-966.

Opejobi, S. (2020). Stop attacking Oyakhilome, evil people can use $5 G$ - Pastor Giwa tells critics. Daily Post. https://dailypost.ng/2020/04/08/stop-attackingoyakhilome-evil-people-can-use-5g-pastor-giwa-tells-critics/

Osuagwu, P. (2020). COVID-19, 5G Mix-up: Why Nigerians are worried On. Vanguard. https://www.vanguardngr.com/2020/04/covid-19-5g-mix-up-why-nigerians-areworried/

Panagopoulos, D. J. (2019). Comparing DNA damage induced by mobile telephony and other types of man-made electromagnetic fields. Mutation Research, 781, 53-62.

Pereira, I. (2020). Cops arrest armed men, Texas bar owner who violated order to close. Abc News. https://abcnews.go.com/US/cops-arrest-armed-men-texas-bar-ownerviolated/story?id=70509866

Radnitz, S., \& Underwood, P. (2017). Is belief in conspiracy theories pathological? A survey experiment on the cognitive roots of extreme suspicion. British Journal of Political Science, 47(1), 113-129.

Ramalan, I. (2020). First Lady bars access to Buhari as Abba Kyari reportedly tests positive for COVID-19. Daily Nigerian. https://dailynigerian.com/first-lady-barsaccess-to-buhari-as-abba-kyari-reportedly-tests-positive-for-covid-19/

Reality Check. (2019). Does $5 G$ pose health risks? BBC News.

Russell, M. (2001). The effective use of secondary data. Learning and Motivation, 33, $32-45$.

Sahara Reporters. (2020). How Buhari's chief of staff, Abba Kyari's, private treatment violates quarantine act. Sahara Reporters. http://saharareporters.com/2020/04/04/how-buhari's-chief-staff-abba-kyari'sprivate-treatment-violates-quarantine-act

Simkó, M., \& Mattsson, M. (2019). 5G wireless communication and health effects-A pragmatic review based on available studies regarding 6 to $100 \mathrm{GHz}$. International Journal of Environmental Research and Public Health, 16, 1-23.

Smith, D. (2020). Wounded by media scrutiny, Trump turned a briefing into a presidential tantrum. The Guardian. https://www.theguardian.com/us-news/2020/apr/13/trumpcoronavirus-meltdown-media-authority 
Stanley-Becker, I. (2018). 'It's the real me': Nigerian president denies he died and was replaced by a clone. Washington Post. https://www.washingtonpost.com/nation/2018/12/03/its-real-me-nigerianpresident-denies-he-died-was-replaced-by-clone/

Sukmono, F. G., \& Junaedi, F. (2019). Citizen Journalism and Online Community Media: A Case Study of pwmu.co. Jurnal The Messenger, 11(2), 198-208. https://doi.org/10.26623/themessenger.v11i2.1173

Sunstein, C. R., \& Vermeule, A. (2009). Conspiracy theories: Causes and cures. Journal of Political Philosophy, 17, 202-227.

The Pulse. (2014). Pastor Chris Supports Abortion? The Pulse. https://www.pulse.ng/gist/bombshell-pastor-chris-supports-abortion/6cwwx $2 \mathrm{~m}$

The Punch. (2019). The family of Pastor Chris Oyakhilome revealed. The Punch. https://punchng.com/the-family-of-pastor-chris-oyakhilome-revealed/

The Source. (2020). Buhari to address Nigerians amidst hunger, anger and banditry. The Source. https://thesourceng.com/buhari-to-address-nigerians-amidst-hunger-angerbanditry/

Van den Bos, K. (2009). Making sense of life: the existential self trying to deal with personal uncertainty. Psychological Inquiry, 20, 197-217.

Van Prooijen, J., \& Douglas, K. M. (2017). Conspiracy theories as part of history: The role of societal crisis situations. Memory Studies, 10(3), 323-333.

Verma, S., Tejaswini, T., \& Pradhan, D. (2019). Harmful Effects Of 5G Radiations: Review. IRAJ-International Conference-ICRRCTEEE- Bengaluru 2019. https://www.researchgate.net/publication/332267703_HARMFUL_EFFECTS_OF 5G_RADIATIONS_REVIEW

Waldmann-Selsam, C., Balmori-de, L. P. A., Breunig, H., \& Balmori, A. (2016). Radio frequency radiation injures trees around mobile phone base stations. Science of the Total Environment, 572, 554-569.

Wallace, J., \& Palder, D. (2020). The Coronavirus Is Delaying Elections Worldwide. Foreign Policy. https://foreignpolicy.com/2020/05/22/coronavirus-electionspostponed-rescheduled-covid-vote/

Waterson, J., \& Hern, A. (2020). How false claims about $5 G$ health risks spread into the mainstream. The Guardian. https://www.theguardian.com/technology/2020/apr/07/how-false-claims-about$5 \mathrm{~g}$-health-risks-spread-into-the-mainstream

Wood, M.J., Douglas, K. ., \& Sutton, R. M. (2012). Dead and alive: Beliefs in contradictory conspiracy theories. Social Psychological and Personality Science, 3(6), 767-773.

Yustitia, S. (2010). Citizen Journalism Melawan Mainstream Media. Jurnal The Messenger, 2(1), 1-9. https://doi.org/10.26623/themessenger.v2i1.277

Zarefsky, J. (2014). Conspiracy arguments in the Lincoln-Douglas debates. N Rhetorical Perspectives on Argumentation, Argumentation Library, 24, 195-209. 